\title{
Wide variations in hospital waiting times and lists
}

Two reports of great interest to patients awaiting hospital treatment and the doctors caring for them were published last week. One, on outpatient waiting times, was a joint effort between the BMA and the Health Services Management Centre in Birmingham.' The other was a guide to hospital waiting lists from the College of Health. ${ }^{2}$ Neither make comforting reading.

\section{Outpatient waiting times}

In September 1984 the BMA published a survey of outpatient waiting times between April 1983 and April 1984 in all 201 health districts in England and Wales. ${ }^{3}$ Over $75 \%$ of districts replied, giving information about the major specialties that showed a net increase in waiting times across six specialties averaging $20 \%$, with, at the extremes, $72 \%$ of districts showing an increase in waiting time for ophthalmology and $38 \%$ showing a fall in waiting times for general medicine.

When the BMA discussed the results of the survey with the Department of Health and Social Security the Department was sceptical of the results. It was agreed to invite the Health Services Management Centre in Birmingham to analyse the BMA's data. That analysis, prepared by John Yates and Kate Wood, has confirmed that outpatient waiting time had deteriorated between 1983 and 1984. The results were discussed by the BMA's council executive on 6 February, when it was agreed to publicise them and send them immediately to the Secretary of State for Social Services.

In their analysis Yates and Wood excluded Wales but they had access to data from more districts than had the BMA. They concluded that there was an increase in both the average minimum and the average maximum waiting time in all specialties between 1983 and 1984. Tables I and II from the report are reproduced here.

The analysis (of a larger number of districts) showed a smaller percentage increase than did the BMA's study "but the general direction of change remained exactly the same."

The authors argue, however, that the changes between 1983

TABI.E I-Average outpatient waiting time in weeks for 163 English districts

\begin{tabular}{|c|c|c|c|c|}
\hline \multirow[b]{2}{*}{ Specialty } & \multicolumn{2}{|c|}{ Minimum wait* } & \multicolumn{2}{|c|}{ Maximum wait* } \\
\hline & 1983 & 1984 & 1983 & 1984 \\
\hline $\begin{array}{l}\text { General medicine } \\
\text { General surgery } \\
\text { Gynaecology } \\
\text { Ophthalmology } \\
\text { Ear, nose, and throat } \\
\text { Orthopaedics }\end{array}$ & $\begin{aligned} 3.4 \\
7.0 \\
8 \cdot 1 \\
11.6 \\
12.5 \\
14.9\end{aligned}$ & $\begin{array}{r}3.7 \\
7.9 \\
8.5 \\
15 \cdot 1 \\
13.6 \\
16.1\end{array}$ & $\begin{array}{r}8 \cdot 5 \\
16 \cdot 3 \\
17.5 \\
19 \cdot 6 \\
22 \cdot 6 \\
28 \cdot 0\end{array}$ & $\begin{array}{r}9 \cdot 1 \\
17 \cdot 9 \\
19 \cdot 0 \\
23 \cdot 9 \\
22 \cdot 7 \\
31 \cdot 7\end{array}$ \\
\hline
\end{tabular}

* Not all districts gave both figures and if one figure was given, which was more likely to be a minimum figure, this was included in both calculations.

TABLE II-Increase in outpatient waiting time expressed as a percentage change between 198.3 and 1984

\begin{tabular}{|c|c|c|c|}
\hline \multirow[b]{2}{*}{ Specialty } & \multicolumn{2}{|c|}{ Analysis of 163 English districts } & \multirow{2}{*}{ 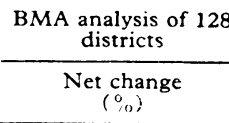 } \\
\hline & $\underset{(0.1)}{\text { Minimum }}$ wait & $\underset{(0)}{\operatorname{Maximum}}$ wait & \\
\hline $\begin{array}{l}\text { General medicine } \\
\text { General surgery } \\
\text { Gynaecology } \\
\text { Ophthalmology } \\
\text { Ear, nose, and throat } \\
\text { Orthopaedics }\end{array}$ & $\begin{array}{l}+9 \\
+13 \\
+\quad 5 \\
+30 \\
+9 \\
+\quad 8\end{array}$ & $\begin{array}{l}+7 \\
+10 \\
+\quad 9 \\
+22 \\
0 \\
+13\end{array}$ & $\begin{array}{l}+18 \\
+19 \\
+17 \\
+39 \\
+26 \\
+15\end{array}$ \\
\hline
\end{tabular}

and 1984 were not the most important findings in the BMA's survey.

"Despite the varying definitions used it has exposed the most enormous variations in performance from district to district across the country. For example, one can obtain an appointment to see an orthopaedic surgeon next week in some districts while in others the first available appointment is next year. It is not so much a National Health Service as a group of local health services with widely differing standards. Perhaps if consumers in these districts were aware of the wide variations they might put more pressure on their district to improve performance. Consumers, clinicians, managers, and politicians should not be concerned about small increases or decreases in national averages but should try to learn why such different lengths of wait occur. Apparently in this country we have some very efficient districtsperhaps other districts have something to learn from them."

Pointing out that the NHS has never collected data about "patients' total waiting experience," Yates and Wood say that as a result of the BMA's survey it was now possible to assess the extent to which inpatient and outpatient waiting time balance each other out.

\section{Report recommends working party to study problems}

Their report continues: "Unfortunately, inpatient waiting time is not collected in terms of weeks, but we do know the percentage of non-urgent patients that wait over one year. Taking orthopaedics as an example, we divided districts' inpatient and outpatient waiting times into three groups.

"Outpatients: under 10 weeks; 11-20 weeks; over 20 weeks. Inpatients: $1-25 \%$ waiting over one year; $26-50 \%$ waiting over one year; over $50 \%$ waiting over one year.

"Plotting districts against these criteria would give us some idea of the balance of waiting time and also a rough idea of what sort of waiting experience to expect in different districts (table III). There was no obvious balancing of waiting time and there are clearly a number of districts with very substantial waiting time problems. If the data is correct this has identified a number of districts that merit special attention. It would be useful to ascertain what problems exist in such districts. We would recommend that representatives from the medical profession and health authorities should set up a working party to visit districts and establish whether such problems are caused by lack of resources, poor management, or other causes."

continued on page 578

TABLE III-Inpatient and outpatient waiting times for orthopaedics in English districts, $1983^{*}$

\begin{tabular}{|c|c|c|c|}
\hline \multirow{2}{*}{$\begin{array}{l}\text { Majority (over } \\
50 \% \text { of inpatients } \\
\text { waiting over a } \\
\text { year } \\
\mathbf{2 6 - 5 0} \% \text { of } \\
\text { inpatients waiting } \\
\text { over a year }\end{array}$} & \multirow{2}{*}{$\begin{array}{l}16 \text { districts: poor } \\
\text { service, especially } \\
\text { for inpatient } \\
\text { waiting } \\
36 \text { districts: } \\
\text { reasonable service } \\
\text { but long inpatient } \\
\text { waiting }\end{array}$} & $\begin{array}{l}9 \text { districts: very } \\
\text { poor service }\end{array}$ & $\begin{array}{l}12 \text { districts: } \\
\text { exceptionally poor } \\
\text { service }\end{array}$ \\
\hline & & $\begin{array}{l}14 \text { districts: poor } \\
\text { service }\end{array}$ & $\begin{array}{l}10 \text { districts: very } \\
\text { poor service }\end{array}$ \\
\hline \multirow[t]{2}{*}{$\begin{array}{l}\text { Few }(1-25 \%) \text { or } \\
\text { no inpatients } \\
\text { waiting over a } \\
\text { year }\end{array}$} & $\begin{array}{l}34 \text { districts: fairly } \\
\text { good service or no } \\
\text { inpatient facilities }\end{array}$ & $\begin{array}{l}14 \text { districts: } \\
\text { reasonable service } \\
\text { (unless no bed } \\
\text { provision) but long } \\
\text { outpatient waiting }\end{array}$ & $\begin{array}{l}12 \text { districts: poor } \\
\text { service in respect of } \\
\text { outpatient waiting } \\
\text { (and possibly no } \\
\text { bed provision) }\end{array}$ \\
\hline & $\begin{array}{l}\text { Fairly short } \\
\text { outpatient } \\
\text { waiting time: } \\
\text { under } 10 \text { weeks }\end{array}$ & $\begin{array}{l}\text { Long outpatient } \\
\text { waiting time: } \\
11-20 \text { weeks }\end{array}$ & $\begin{array}{l}\text { Very long } \\
\text { outpatient waiting } \\
\text { time: over } 20 \\
\text { weeks }\end{array}$ \\
\hline
\end{tabular}

The table shows data for only 157 districts, as information about outpatient waiting ime in the remaining 36 districts was not available. 


\section{BMA congress, Cairo}

The bookings for the BMA congress in Cairo, 14 to 18 October; have been closed. From now onwards registrations will be accepted only from people travelling from the United Kingdom who have confirmed bookings with the official travel agent, Fishley Sebley Associates (Travel) Limited. The travel agent will maintain a waiting list in the event of cancellations.

The BMA urged doctors to book early and as expected all the tours have proved very popular. The association is sorry that some doctors who wanted to join the tours have been disappointed. It hopes to be able to hold the 1987 scientific congress in an equally interesting venue.

\section{Claire Wand fund}

Dr Solly Wand, who died last year, set up a trust fund in 1954 in memory of his first wife to promote general practitioner education. Dr Wand used the money donated by grateful general practitioners for his efforts in achieving a $100 \%$ increase in remuneration in the Danckwerts award in 1952. His son, Dr L G Wand, has been elected to chair the trust fund.

The fund can help...

- individual NHS general practitioners to obtain further education.

- appropriate organisations which provide medical education to general practitioners.

- provide scholarships (or travelling fellowships) to general practitioners who wish to study in the United Kingdom or abroad. Grants for these will be made up to a maximum of $£ 500$ for travel in the United Kingdom; $£ 750$ for travel in Europe; and $£ 1000$ for travel elsewhere.
General practitioners who would like to apply for help from the fund should write to Mrs Lavinia Webb, BMA House, Tavistock Square, London WC1 9JP.

\section{"Tax for the newly qualified doctor"}

A new leaflet has been prepared by the BMA's taxation advisory service to help the newly qualified doctor. The leaflet, "Tax for the newly qualified doctor," outlines how the tax system works, explains PAYE, and emphasises the importance of having the correct tax code-on an emergency code the newly qualified doctor would probably pay too much tax. The leaflet illustrates what allowances and expenses can and cannot be claimed and warns that all income (including, for example, payments for cremation fees) must be declared. It is tax leaflet seven in the BMA's series and is available free of charge to BMA members and associate members only from local BMA offices. Members should quote their membership number, and a stamped, addressed envelope $\left(9^{\prime \prime} \times 6^{\prime \prime} 17 \mathrm{p}\right.$ or 13p) will help speed despatch.

\section{BUPA benefit levels : consultants' private fees}

After abortive discussions with representatives of the British United Provident Association, the CCHMS has decided to withdraw its recommendation of two years ago that consultants should continue their customary practice of setting fees at a level that could be expected to be covered by the benefits available to adequately insured patients. For the third year in succession, the CCHMS was told, BUPA had refused to increase its benefit levels for consultants' fees. It had not, however, hesitated to increase its benefit levels in respect of hospital charges for each of those three years. Meanwhile, the CCHMS decided to seek a further meeting with BUPA.

\section{NHS performance indicators and option appraisal}

For all their problems performance indicators in the National Health Service are here to stay. That is the conclusion in a discussion paper from the health economics research unit at the University of Aberdeen.' The House of Commons public accounts committee has $\overrightarrow{\vec{\omega}}$ been urging the Department of Health and $\omega$ Social Security to develop a system which would provide "the means to monitor key indicators of performance" in the NHS. The iN discussion paper has found that the information produced by the DHSS to help regional o and district health authorities assess their $\vec{a}$ performance raises more questions than it. answers. The DHSS gives no information on how the results are to be interpreted.

A second paper from the unit looks at 을 option appraisal in the NHS. ${ }^{2}$ All major capital $\overrightarrow{\vec{\sigma}}$ schemes in the NHS now have to be subject to economic or option appraisal-what to $\mathbb{D}$ build, what size, where and what specialties to place in new developments-to ensure value for money. In principle, the unit says, this should have led to more rational decisions and $\overrightarrow{0}$ greater efficiency in the use of resources. The paper assesses why and how obstacles have hindered the effective use of option appraisal and suggests how the problems might be resolved.

1 Ferguson B, McGuire A. A short history and review of performance indicators issued by the DHSS. Aberpeen. University of Aberdeen, 1984. (Discussion paper No 09/84.

2 Mooney. G, Henderson J. Option appraisal in the NHS. the road lo eftiency? Aberdeen. University

Waiting times and lists-continued from page 577

\section{Nearly 30000 patients wait for over one month for urgent treatment}

The college's guide-its second edition-confirms that the length of hospital waiting lists remains a serious problem. On 31 March 1984692945 patients were awaiting admission to hospital in England alone. The DHSS objective is that urgent patients should not wait for longer than a month and non-urgent patients no longer than a year. The college says, however, that 29283 urgent cases had been waiting longer than a month and 194614 non-urgent cases had been waiting for more than a year.

Last year's first edition gave NHS waiting lists district by district, so enabling patients facing a wait of years at their local hospital to ask for referral to a more distant hospital with a shorter waiting time for the operation in question. Within a few months many patients had written to the college reporting that after waiting for years they had either had their operation in another hospital or been reassessed and given priority in their own unit.

The college is now worried that in some health authorities, especially those in inner cities, which have been the subject of financial restrictions, administrators may be refusing to accept patients from other districts or regions. Such action may, it reports, be contrary to the NHS Act. The College of Health 8 fears that if this type of restriction were to become widespread 3 it would lengthen already long waiting lists and add to existing $\mathrm{O}$ pressures to patients who are stuck on long waiting lists to opt for private treatment instead.

Concerned that these waiting lists may lead to queue jumping $\frac{D}{0}$ by patients prepared to pay for private care, the college calls for more information, suggesting that the DHSS should support "a $N$ carefully designed research project on the problem." It has also N asked members of the public and consultants to write to the $\sigma$ college about their own experiences and difficulties of the NHS/ 0 private practice dilemma caused by long waiting lists.

The guide concludes that most patients who have been waiting $\stackrel{0}{+}$ for over a year to enter hospital are victims of a local problem. $T$ "Most districts where there is a long wait for a particular branch $\overrightarrow{+}$

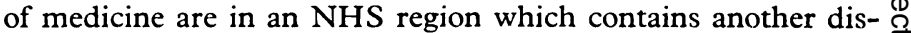
trict, often quite nearby, where there is only a short wait."

1 Yates J, Wood K. Out-patient waiting times. Birmingham: Health Services $ᄋ$ Management Centre, 1985. College of Health. The college

Anonymous. BMA survey shows major increase in hospital waiting times. Br Med $\mathcal{f} \frac{\text { }}{\partial}$ 984;289:775. 